Egyptian Journal of Aquatic Biology \& Fisheries

Zoology Department, Faculty of Science,

Ain Shams University, Cairo, Egypt.

ISSN $1110-6131$

Vol. 23(2): 379 - 396 (2019)

www.ejabf.journals.ekb.eg

\title{
Environmental Remediation of Tilapia Aquaculture Wastewater Using Ceratophyllum demersum and Lemna minor.
}

\author{
Mokhtar Beheary ${ }^{1}$, Basma M. Sheta ${ }^{2} *$ Menna Hussein $^{2}$, Mona Nawareg ${ }^{2}$, \\ Fatma A. El-Matary ${ }^{3}$ and Ayman Hyder ${ }^{2}$ \\ 1- Environmental Science Department, Faculty of Sciences, Port Said University. \\ 2- Zoology Department, Faculty of Science, Damietta University, Egypt. \\ 3- National Institute of Oceanography and Fisheries, Egypt \\ *Corresponding author: basmasheta@du.edu.eg
}

\section{ARTICLE INFO \\ Article History: \\ Received: April 28, 2019 \\ Accepted: May 12, 2019 \\ Online: May 18, 2019}

Keywords:

Oreochromis niloticus

Phytoremediation

Ceratophyllum demersum

Lemna minor

Aquaculture

Wastewater

Pollution

\section{ABSTRACT}

Two aquatic macrophytes, Ceratophyllum demersum and Lemna minor, were used in aquaculture wastewater treatment. Tilapia fish (Oreochromis niloticus) with total body weight of 50-60 $\mathrm{g}$ were placed in $60 \mathrm{~L}$ aquaria. Four treatment groups were included: control (no plant treatment, depended on artificial filtering for purification), Lemna minor $(\mathrm{Lm})$, Ceratophyllum demersum $(\mathrm{Cd})$, and mixed plants group $(\mathrm{Lm}+\mathrm{Cd})$. Each group had three replicates (5 fish/replicate). The experiment was conducted for 4 weeks. Physicochemical parameters of aquaculture wastewater including $\mathrm{pH}$, total dissolved solids (TDS), conductivity, turbidity, dissolved oxygen (DO), chemical oxygen demand (COD), biochemical oxygen demand (BOD), total phosphorous $\left(\mathrm{TPO}_{4}\right)$, nitrate $\left(\mathrm{NO}_{3}\right)$, nitrite $\left(\mathrm{NO}_{2}\right)$, and ammonia were determined. The results reflected more effective removal of pollutants from fish aquaria by both plants than that by the artificial aeration/filtering. The effectiveness of pollution removal was higher in $C d$ group $>\mathrm{Lm}>\mathrm{Lm}+\mathrm{Cd}$, compared to the control. This order of phytoremediation was confirmed by improvements in tilapia fish health status including liver function (AST, ALT, albumin), kidney function (creatinine, urea, uric acid), in addition to other nutritional and hematological parameters. It could be concluded that the phytoremediation using $C$. demersum is ecofriendly and effective in removing contaminants from Tilapia aquaculture wastewater and therefore, it is recommended to be applied in tilapia farms.

\section{INTRODUCTION}

Huge amounts of freshwater are required for intensive aquacultures, which generate nutrient-rich wastewater streams, causing eutrophication and negatively impact aquatic biological communities. Reduction of nutrient and chemical discharge into receiving water bodies always needs sustainable water treatment technologies (Islam and Tanaka 2004, and Wuang et al., 2016). In this context, aquatic plants have been widely used to remove pollutants from wastewaters. Floating and emergent plants have been studied for nutrient and heavy metal removal from different types of wastewater (Seo et al., 2010; Tel-Or and Forni, 2011). Pollutant removal studies by aquatic plants have been applied on aquaculture pond effluent (Sooknah and Wilkie, 2004; Mohedano et al., 2012). Iamchaturapatr et al. (2007) examined diverse types 
of plants species, including 21 types of floating and emergent aquatic plants, and found that different types of plants had different nitrogen and phosphorus removal capacity. Using floating aquatic plants in treatment of wastewater was found to be more preferable because of their higher growth rate. They are easier to maintain and harvest after the treatment (Tel-Or and Forni, 2011). In addition, the harvested biomass can be utilized for many purposes such as animal feeding or feedstock for renewable energy production (Muradov et al., 2014; and Sudiarto et al., 2019).

Ceratophyllum demersum L. (Ceratophyllaceae, horn weed or coontail) grows in shallow, muddy, quiescent water bodies at low light intensities. It is a submerged, rootless, free floating, perennial and it is cosmopolitan in distribution. This submerged macrophyte has a high capacity for vegetative propagation and biomass production even under low nutritional conditions, removing excess nutrients and metals from stagnant waters. It is useful as an oxygenator or for use in a closed equilibrated biological aquatic system (Aravind and Prasad, 2005 and Foroughi et al., 2010). Lemna minor (duckweed) is the world's smallest and fastest growing angiosperm (Ziegler et al., 2016). It represents a suitable producer of large amounts of biomass and has a great economic potential and many practical applications in biotechnological and ecological fields (Tel-Or and Forni, 2011). Lemna minor species are used as bio-indicators for in situ and ex situ ecotoxicological assays (Brain and Solomon, 2007). The efficacy of this plant to remove nutrients, and heavy metal sequestration ability from wastewaters and creation of habitat for aquatic organisms capable of metabolizing wastewater organics are previously published (Louis et al., 2005). In addition, species of this plant were reported to be very effective for the removal of soluble salts, organic matter, algal abundance and coliform densities (El-Kheir et al., 2007) and it can tolerate elevated organic loading as well as high concentrations of micronutrients (Hasan and Chakrabarti, 2009). Furthermore, such systems were reported for their capacity to reduce odors and inhibit mosquito breeding besides the production of useful biomasses (Gupta and Prakash, 2014; Amare et al. 2018). Different fish species were largely used for the assessment of aquatic environment quality and are accepted as bio-indicators of environmental pollution (Beheary et al., 2015). They are in close contact with their environment, and are very susceptible to physical and chemical changes, which may be seen in their blood components (Ayoola et al., 2014, Beheary et al., $2018 \mathrm{a \& b}$ ).

The objective of this study was to examine the efficiency of using some plants in removing pollutants from aquaculture. Two aquatic macrophytes were used in this study: the submerged Ceratophyllum demersum and the floating Lemna minor. Physicochemical parameters of aquaculture wastewater including $\mathrm{PH}$, total dissolved solids (TDS), conductivity, turbidity, dissolved oxygen (DO), chemical oxygen demand (COD), biochemical oxygen demand (BOD), total phosphorous (TPO4), nitrate (NO3), nitrite (NO2) and ammonia have been analyzed. The variation in physicochemical parameters of aquaculture wastewater was determined to verify the effectiveness of plant-based treatment process. This study also assessed some hematological and physiological indices of Tilapia (Oreochromis niloticus) with respect to treatment processes.

\section{MATERIALS AND METHODS}

\section{Fish}

The experiment was held in the Department of Zoology Laboratory, Damietta Faculty of Science. Healthy and active specimens of Tilapia Fish (Oreochromis 
niloticus), Cichlidae with total body weight (50-60 g) were obtained from Alabsho fish farm. The fish were handled very softly to avoid any injury and treated with $0.1 \%$ KMNO4 solution for removal of any fungal infection. Groups of 5 fish were kept in a $60 \mathrm{~L}$ glass aquarium loaded with $40 \mathrm{~L}$ of de-chlorinated tap water and gently aerated for two weeks for acclimatization. Fish were fed twice every day at a rate of $3 \%$ of their biomass.

Plants

Ceratophyllum demersum and Lemna minor were collected from fresh water canals in Damietta and thoroughly washed with tap water to remove any soil sediment particles attached to the plant surfaces. Plants were placed in fish-free aquaria $(60 \mathrm{~L})$ for 2 days before being added to the test aquaria.

\section{Experimental design}

Fish were divided into 4 treatment groups of 3 replicates per group, and 5 fish/replicate. The control group was not exposed to any phyto-treatment but continued on pump aeration and waste filtering as in the acclimatization period. The second group was treated with Lemna minor $(\mathrm{Lm})$, while the third group was treated with Ceratophyllum demersum $(C d)$. The fourth group was treated with both Ceratophyllum demersum and Lemna minor $(\mathrm{Lm}+\mathrm{Cd})$. All treatments continued for 4 weeks.

\section{Analyses}

Water samples were collected from each aquaria every 7 days to measure $\mathrm{PH}$, turbidity, temperature, Total dissolved solids (TDS), conductivity (EC), dissolved oxygen (DO), chemical oxygen demand (COD), biochemical oxygen demand (BOD), total Phosphorous, ammonia $\left(\mathrm{NH}_{3}\right)$, nitrate $\left(\mathrm{NO}_{3}\right)$ and Nitrite $\left(\mathrm{NO}_{2}\right)$.

Water temperature was measured using protected thermometer. $\mathrm{PH}$ was carried out using a pH-meter (PH-Lutron, Model 206). TDS and conductivity (EC) were carried out by TDS/EC meter (Lutron, Model YK-22CT). Turbidity was measured by nephelometric Method using Al 1000 Turbidimeter, Aqualytic, Germany, with measuring range of 0-200 NTU.

Dissolved oxygen, nutrient salts, biological oxygen demand and chemical oxygen demand were determined according to APHA (2005). Dissolved oxygen, biological oxygen demand, chemical oxygen demand, total phosphorous, ammonia $\left(\mathrm{NH}_{3}\right)$, nitrate $\left(\mathrm{NO}_{3}\right)$, nitrite $\left(\mathrm{NO}_{2}\right)$ were determined according to APHA (2005).

At the end of the experiment (4 weeks), blood samples were collected from the caudal vein via heparinized syringe. Hematological variables include white blood cell count (WBCx $\left.10^{3} / \mathrm{L}\right)$, hemoglobin concentration $(\mathrm{Hb}, \mathrm{g} / \mathrm{dL})$, hematocrit $(\mathrm{Ht}, \%)$, red blood cell count $\left(\mathrm{RBCx} 10^{6} / \mathrm{L}\right)$, mean corpuscular volume $(\mathrm{MCV}, \mathrm{fL})$, mean corpuscular hemoglobin $(\mathrm{MCH}, \mathrm{g} / \mathrm{dL})$ and mean corpuscular hemoglobin concentration (MCHC, g/dL) and were analyzed on a mindary BC-2800 Auto Hematology Blood Analyzer. Plasma was obtained from blood samples by centrifugation at $3000 \mathrm{rpm}$ for $15 \mathrm{~min}$ at room temperature. Biochemical variables included total protein, albumin, glucose, cholesterol, triglyceride, creatinine, uric acid, urea, Aspartate Aminotransferase (AST, formerly GOT) and Alanine Aminotransferase (ALT, formerly GPT) concentrations were determined by using a Roche Hetachi Cobas C311.

\section{Statistical analysis}

Data are presented as mean \pm SEM. For all statistical analyses, Microsoft Excel was used. Significant differences among different plant treatments and different measured water variables and blood variables were tested by using one-way analysis 
of variance (ANOVA). Unpaired t-test was applied as a post-hoc test, when ANOVA was significant. In all cases, a $\mathrm{p}$ value of less than 0.05 was considered as significant.

\section{RESULTS AND DISCUSSION}

The aim of this study was to examine the efficiency of using the submerged Ceratophyllum demersum and the floating Lemna minor in removing pollutants from tilapia aquaculture. Unfortunately, we could not compare the results with a control tilapia aquarium without artificial aeration/filtering. These aquaria became very turbid and contaminated quickly so that fish could not survive this contamination for a reasonable period. Thus, the aeration pump and artificial filter were recruited in the control group, and the study compared the artificial wastewater purification in this control group with that by the applied plants. It was very obvious that the aquaria with Ceratophyllum demersum $(C d)$ were cleaner and clearer than all other treatments (Fig. 1).

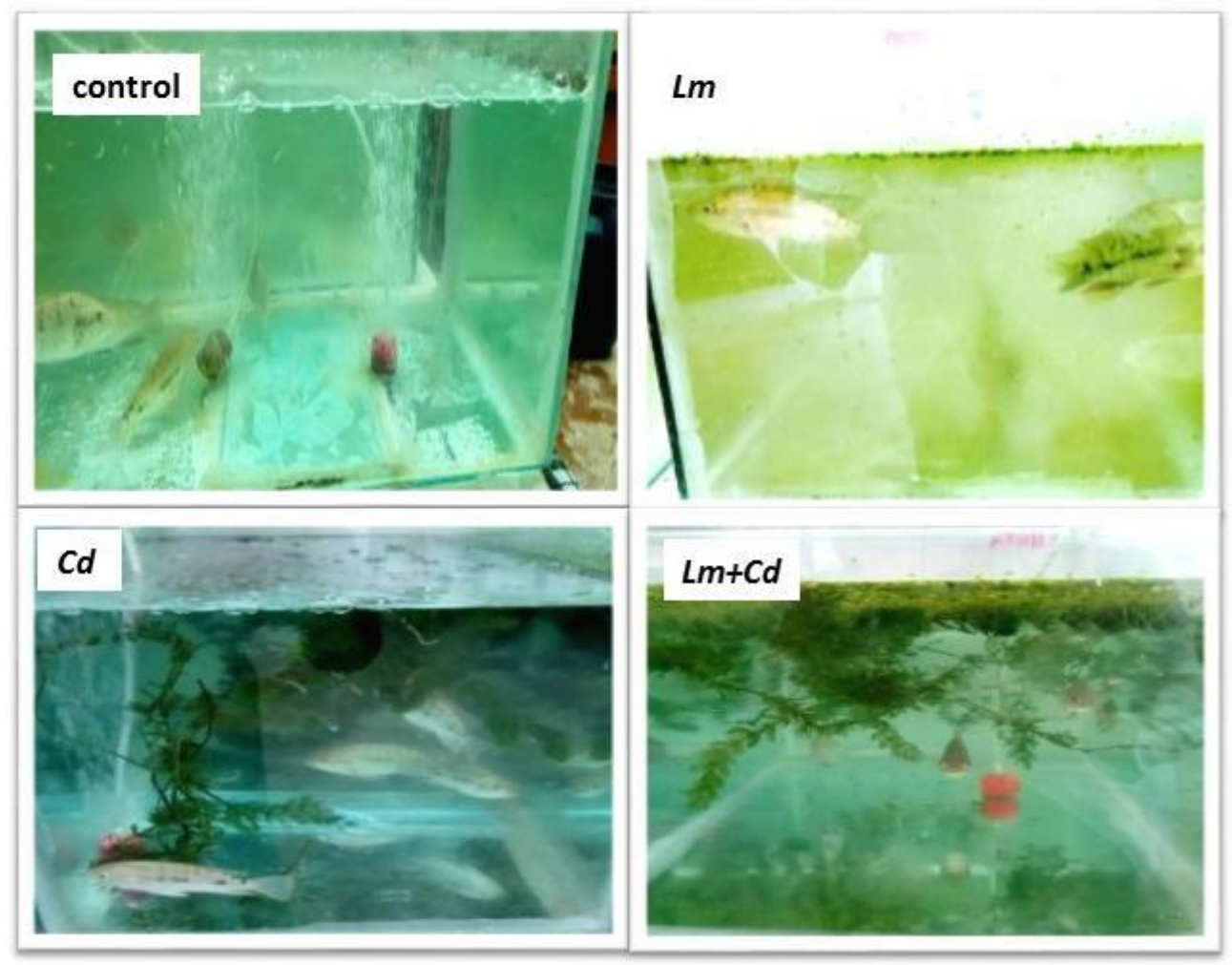

Fig. 1: Photographs of tilapia aquaria after 4-week-treatment with Lemna minor (Lm), Ceratophyllum demersum $(\mathrm{Cd})$ or mix of them $(\mathrm{Lm}+\mathrm{Cd})$.

\section{Water quality}

Physicochemical parameters were measured once a week in water samples collected from each treatment (Fig. 2). The obtained results for temperature, $\mathrm{pH}$, turbidity, conductivity (EC), TDS, dissolved oxygen (DO), chemical oxygen demand (COD), biochemical oxygen demand (BOD), total phosphorous $\left(\mathrm{TPO}_{4}\right)$, ammonia $\left(\mathrm{NH}_{3}\right)$, nitrate $\left(\mathrm{NO}_{3}\right)$, and nitrite $\left(\mathrm{NO}_{2}\right)$ are presented in Table (1). Water temperatures were almost similar in all treatments and ranged from $24.3^{\circ} \mathrm{C}$ to $24.6^{\circ} \mathrm{C}$. 
Table 1: Physicochemical characteristics of water samples collected from aquaria treated with Lemna minor $(\mathrm{Lm})$, Ceratophyllum demersum $(\mathrm{Cd})$ or mixed group of Lemna minor and Ceratophyllum demersum $(\mathrm{Lm}+\mathrm{Cd})$.

\begin{tabular}{|c|c|c|c|c|c|}
\hline & Control & $L m$ & $C d$ & $L m+C d$ & ANOVA $p=$ \\
\hline Temp $\left({ }^{\circ} \mathrm{C}\right)$ & $24.48 \pm 0.04$ & $24.48 \pm 0.07$ & $24.40 \pm 0.14$ & $24.45 \pm 0.09$ & 0.723 \\
\hline $\mathrm{pH}$ & $7.60 \pm 0.09$ & $7.76 \pm 0.06$ & $7.50 \pm 0.11^{\mathrm{b}}$ & $7.92 \pm 0.05^{\mathrm{a}}$ & 0.0148 \\
\hline Turbidity (NTU) & $26.19 \pm 0.17$ & $25.03 \pm 0.36$ & $23.87 \pm 0.21^{\mathrm{a}, \mathrm{b}}$ & $25.66 \pm 0.06$ & 0.00007 \\
\hline Conductivity $(\mu \mathrm{S}-1)$ & $0.65 \pm 0.09$ & $0.59 \pm 0.05$ & $0.49 \pm 0.01^{\mathrm{a}, \mathrm{b}}$ & $0.62 \pm 0.02$ & 0.0217 \\
\hline Total solids (mg/l) & $483.25 \pm 35.5$ & $364.25 \pm 15.6^{\mathrm{b}}$ & $319.75 \pm 4.3^{\mathrm{a}, \mathrm{b}}$ & $436.5 \pm 14.7^{b}$ & 0.00059 \\
\hline $\mathrm{DO}(\mathrm{mg} / \mathrm{l})$ & $3.89 \pm 0.1$ & $3.85 \pm 0.1^{\mathrm{b}}$ & $3.70 \pm 0.12^{\mathrm{b}}$ & $3.55 \pm 0.13^{\mathrm{a}, \mathrm{b}}$ & 0.01847 \\
\hline $\mathrm{COD}(\mathrm{mg} / \mathrm{l})$ & $219.38 \pm 1.95$ & $207.33 \pm 1.02^{\mathrm{a}, \mathrm{b}}$ & $205.75 \pm 1.25^{\mathrm{a}, \mathrm{b}}$ & $215.75 \pm 0.85^{\mathrm{b}}$ & 0.000022 \\
\hline BOD $(\mathrm{mg} / \mathrm{l})$ & $14.81 \pm 0.19$ & $14.33 \pm 0.16^{\mathrm{b}}$ & $13.63 \pm 0.22^{\mathrm{a}, \mathrm{b}}$ & $15.18 \pm 0.16^{\mathrm{b}}$ & 0.00166 \\
\hline Ammonia (mg/l) & $9.75 \pm 0.16$ & $9.51 \pm 0.12^{b}$ & $9.42 \pm 0.14^{\mathrm{a}, \mathrm{b}}$ & $9.66 \pm 0.11^{\mathrm{b}}$ & 0.0038 \\
\hline nitrite $(\mathrm{mg} / \mathrm{l})$ & $31.58 \pm 0.97$ & $27.4 \pm 0.93^{\mathrm{a}}$ & $25.96 \pm 1.53^{\mathrm{a}}$ & $29.26 \pm 0.43^{\mathrm{b}}$ & 0.01333 \\
\hline nitrate $(\mathrm{mg} / \mathrm{l})$ & $33.55 \pm 0.17$ & $31.64 \pm 0.35^{\mathrm{a}}$ & $30.7 \pm 0.63^{\mathrm{a}, \mathrm{b}}$ & $31.5 \pm 0.50^{\mathrm{a}}$ & 0.0046 \\
\hline TPO4 (mg/l) & $33.73 \pm 0.1$ & $33.08 \pm 0.16^{\mathrm{a}, \mathrm{b}}$ & $32.25 \pm 0.35^{\mathrm{a}, \mathrm{b}}$ & $34.0 \pm 0.14^{\mathrm{b}}$ & 0.00017 \\
\hline
\end{tabular}

Data are averages of 4 weeks of treatment and presented as mean \pm SEM. Statistical analyses: ANOVA $\mathrm{p}$ values are mentioned in the table; post-hoc unpaired t-test: $\mathrm{a}=$ significantly different from the control value, $b=$ significantly different from values of other treatments. $\mathrm{DO}=$ Dissolved Oxygen, $\mathrm{COD}=$ Chemical Oxygen Demand, BOD = Biological Oxygen Demand, TPO4 $=$ Total Phosphorous.

The results indicated that $\mathrm{pH}$ value were significantly increased to be more alkaline in $\mathrm{Lm}+\mathrm{Cd}$ treatment with average of 7.92 followed by $\mathrm{Lm}$-treatment with average of 7.76, while it was significantly lower in the $C d$ group than that in all other treatment (Table 1). However, it is known that most fish can tolerate $\mathrm{pH}$ values of about 5.0 to 9.0. Although these small changes in $\mathrm{pH}$ are not likely to have a direct impact on aquatic life, they greatly influence the availability and solubility of all chemical forms in the water and may aggravate nutrient problems (Ahmed, et al. 2013). An increase in $\mathrm{pH}$ level supports the growth of aquatic plants. Kashim and Singh (2002) reported that due to increase of $\mathrm{pH}$, there was an increase in the uptake of elements. This is the reason that initially relative growth rate of treated plants significantly increased with the passage of time (Saha et al., 2015).

Turbidity is a relative measurement of reduced visual clarity. Increased turbidity levels are caused by suspended particles dissolved organic matter, and planktonic organisms in the water column. In the current study, turbidity was increased in the control during the experiment period to reach the highest value at the end of the experiment (26.61 NTU, Fig. 2). Turbidity was reduced significantly in the other treatments. The values reduced in $L \mathrm{~m}$ treatment from 25.7 to $24.03 \mathrm{NTU}$, in $C d$ treatment from 24.4 to 23.49 NTU, and in the mixed treatment from 25.75 to 25.50 NTU (Fig. 2). The turbidity in the Cd group was significantly lower than that of the control and the other treatment groups (Table1). In general, the percent removal of turbidity between groups was arranged as: $C d$ treatment $(8.85 \%)>\mathrm{Lm}$ treatment $(4.42)>L m+C d(2 \%)$ compared to the control. Turbidity reduction might be attributed to the reduction in suspended particulates particularly the organic matter (Gopal and Ghosh, 2008). An increase in transparency and a major reduction in the biological oxygen demand $\left(\mathrm{BOD}_{5}\right)$ may also result. The obtained results were in conformity with Tanner and Headley (2011) and White and Cousins (2013) who suggested that the use of floating treatment wetlands has the advantages of enhanced sedimentation of particles, and facilitating nutrient and metal removals.

Conductivity is a measure of how well water can pass an electrical current. It is an indirect measure of the presence of inorganic dissolved solids. Reductions in EC values were observed in the three treatment groups from the initial measurement to the end of the experiment with averages of $0.49,0.59,0.62$ for $C d$ treatment, $\mathrm{Lm}$ treatment, $L m+C d$, respectively, while an increase in EC values in the control group 
was noticed (Fig. 2). The average conductivity was significantly lower in $C d$ group than all other tested groups (Table 1). The maximum percent reduction of EC was observed in $C d$ treatment (24.5\%) followed by $L m$ treatment $(9.4 \%)$ and $L m+C d 4.5$ $\%$ compared with the control. Our results are in agreement with that of Foroughi et al. (2014), who found that the EC values in diluted fresh latex wastewater was reduced by the use of $C d$ from 0.75 to $0.65 \mathrm{ds} / \mathrm{L}$.

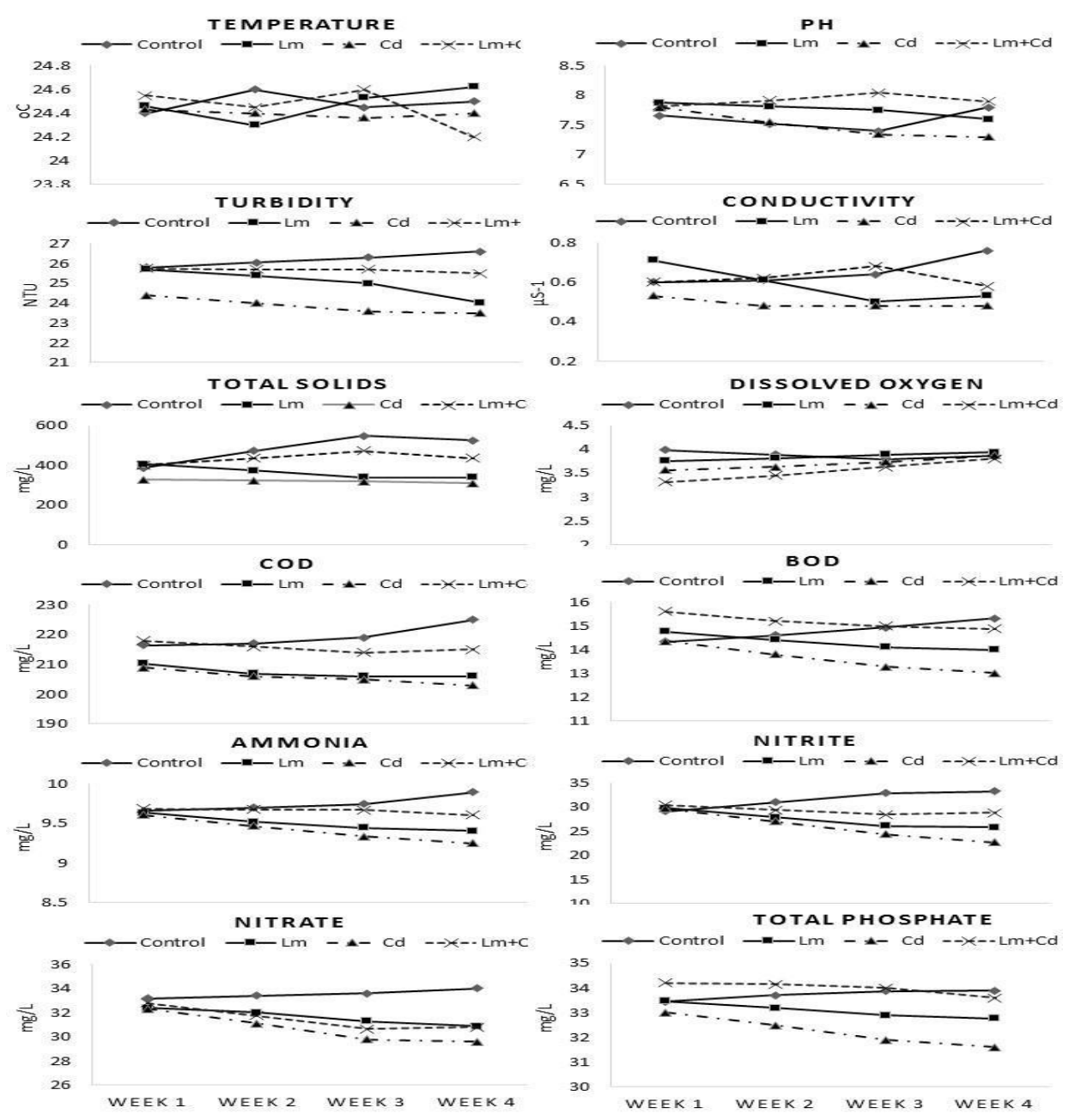

Fig. 2: Weekly changes in tilapia aquaculture water physicochemical parameters in response to treatment with Lemna minor $(\mathrm{Lm})$, Ceratophyllum demersum $(\mathrm{Cd})$ or mix of them $(\mathrm{Lm}+\mathrm{Cd})$.

A high level of total dissolved solids (TDS) was quantified in the control after the 4-week-study $(525 \mathrm{mg} / \mathrm{l})$ compared to the initial value $(388 \mathrm{mg} / \mathrm{l})$. All other treatments decreased TDS values as compared to initial values. When comparing the reduction percent of TDS among treatments and control, we found that treatment with $C d$ reduced TDS by $33.8 \%$ followed by $L m$ treatment $(24.6 \%)$ and $L m+C d$ $(9.6 \%)$. The difference between groups was significant (Table 1). In accordance with our results, Saha et al. (2015) reported that the phytoremediation technique has the capacity to reduce TDS levels in wastewater.

Dissolved oxygen content (DO) in $\mathrm{Lm}$ treatment, $\mathrm{Cd}$ treatment, and $\mathrm{Lm}+\mathrm{Cd}$ tended to increase significantly from the beginning $(3.76,3.57,3.32 \mathrm{mg} / \mathrm{l})$ to the end of experiment $(3.94,3.87,3.81 \mathrm{mg} / \mathrm{l})$, respectively (Fig. 2). In contrast, the control DO content decreased during the experiment from $3.99 \mathrm{mg} / \mathrm{l}$ to $3.86 \mathrm{mg} / \mathrm{l}$ at the end of the experiment. The average concentrations of DO over the experiment period were significantly lower in $C d$ treatment and $L m+C d$ treatment (table 1) perhaps 
because the presence of plants covering the surface resulted in lower chances for oxygen exchange between the water surface and atmosphere. Generally, the highest average concentration of DO was recorded in the control group with no plants.

Chemical oxygen demand (COD) and biochemical oxygen demand (BOD) are important parameters for determining the amount of organic and inorganic pollution in water. The present results showed that COD content in the control group increased gradually from $216.5 \mathrm{mg} / \mathrm{l}$ in the first week to $225 \mathrm{mg} / \mathrm{l}$ at the end of experiment. Relatively, reduction of COD from the beginning to the end of experiment was observed in $L m$ treatment ( 210.3 to $206 \mathrm{mg} / \mathrm{l}$ ), $C d$ treatment (209 to $203 \mathrm{mg} / \mathrm{l}$ ) and $\mathrm{Lm}+\mathrm{Cd}$ treatment (218 to $2015 \mathrm{mg} / \mathrm{l}$ ). A remarkable removal percent among groups was detected, as $C d$ treatment reduced COD concentrations by $6.2 \%$ over the control, followed by $L m$ treatment $(5.4 \%)$ and $L m+C d$ treatment $(1.6 \%)$.

BOD content increased significantly in the control group from 14.35 to 15.33 $\mathrm{mg} / \mathrm{l}$ at the end of the experiment (Fig. 2). The values decreased highly during the experiment in all other treatments. Treatment with $C d$ reduced BOD from 14.36 to $13.03 \mathrm{mg} / \mathrm{l}$. $\mathrm{Lm}$ treatment reduced BOD from 14.77 to $14 \mathrm{mg} / \mathrm{l}$, and $\mathrm{Lm}+\mathrm{Cd}$ treatment reduced BOD from 15.62 to $14.88 \mathrm{mg} / \mathrm{l}$. The highest percent removal of BOD was recorded in $C d$ treatment (7.9\%) with a significant average of $13.63 \mathrm{mg} / \mathrm{l}$ (table 1). The decrease in COD and BOD concentrations in the three treatments was in agreement with the findings of Koèrner and Vermaat (1998), Komer et al. (2003), Pilon-Smits (2005) and Gupta and Prakash (2014). El-Kheir et al. (2007) suggested that aquatic macrophytes played an important role in removing organic contaminants. Previous works such as Gupta and Prakash (2014) reported that duckweed-based wastewater treatment significantly reduced total suspended solids, biochemical oxygen demand, and chemical oxygen demand besides nutrient extraction. Komer et al. (2003) reported that duckweed ponds as wastewater treatment can be qualified as a secondary or tertiary treatment in removing suspended solids (65-70\%) and organic matter (30-45\% BOD).

Aquaculture wastewater often contains high concentrations of ammonia, nitrates, and phosphates (Ziegler et al., 2016). In the present study, ammonia content was increased in the control group, despite filters, from an initial $9.66 \mathrm{mg} / \mathrm{l}$ to 9.9 $\mathrm{mg} / \mathrm{l}$ at the end of experiment with average concentrations of $9.75 \mathrm{mg} / \mathrm{l}$. Ammonia content was reduced in the three treatments compared to control. This reduction was significant only in $C d$ treatment group (Table 1). $C d$ treatment was the best in removing ammonia content with $3.44 \%$ and average concentrations of $9.42 \mathrm{mg} / \mathrm{l}$ followed by $\mathrm{Lm}$ treatment $(2.53 \%$, and $9.51 \mathrm{mg} / \mathrm{l}$ average) and the mixed group $(0.92 \%$, and $9.66 \mathrm{mg} / \mathrm{l}$ average). Ammonium ions can be volatilized as ammonia so that the $\mathrm{NH}_{4}{ }^{+}$concentration in the water is reduced. At $\mathrm{pH}$ more than 7 , the equilibrium of $\mathrm{NH}_{3} / \mathrm{NH}_{4}{ }^{+}$is shifted towards ammonia $\left(\mathrm{NH}_{3}\right)$ (Metcalf and Eddy, 2003, Sudiarto et al., 2019). High ammonia concentrations in the environment are toxic to plants, animals, and even humans (Britto and Kronzucker 2002). As comparison to the present results, Muradov et al. (2014) reported that the removal efficiency for duckweed and azolla plant was $54.9 \%$ and $43.0 \%$, respectively. Huang et al. (2013), Zhang et al. (2014) and Wang et al. (2014) reported that the aquatic plant (Lemna minor) takes up $\mathrm{NH}_{4}{ }^{+}$readily and grows well at concentrations of the ion of up to $84 \mathrm{mg} / \mathrm{l}$, it takes up $\mathrm{NH}_{4}{ }^{+}$and $\mathrm{NO}_{3}{ }^{-}$through both roots and the lower surface of the fronds, and may prefer $\mathrm{NH} 4+$ to $\mathrm{NO}_{3}$ (Fang et al. 2007). Nevertheless, the higher $\mathrm{NH}_{4}^{+}$concentrations still lead to growth rate reduction and photosynthetic pigment loss. 
Nitrate and nitrite were removed efficiently throughout the three treatments compared to the control. As compared with control values, $\mathrm{NO}_{3}$ percent removals were arranged as $8.5 \%(\mathrm{Cd}$ treatment $)>6.11 \%(\mathrm{Lm}+\mathrm{Cd}$ treatment $)>5.7 \%(\mathrm{Lm}$ treatment). While $\mathrm{NO}_{2}$ percent removals were arranged as: $17.79 \%$ (Cd treatment) $>$ $13.22 \%(\mathrm{Lm}$ treatment $)>7.32 \%(\mathrm{Lm}+\mathrm{Cd}$ treatment $)$. The results are similar to that of Muradov et al. (2014), who reported that over $90 \%$ of the $\mathrm{NH}_{4}{ }^{+}$, and $70 \%$ of the $\mathrm{NO}_{3}$ were removed by Spirodela polyrhiza, and Lemna gibba / L. minor, respectively, from wastewater.

A significant reduction in the total phosphorous $\left(\mathrm{TPO}_{4}\right)$ values was observed in $\mathrm{Lm}$ treatment and $\mathrm{Cd}$ treatment (Table 1). Values of both groups and the mixed treatment decreased from initial $(33.46,33.0$, and $34.2 \mathrm{mg} / \mathrm{l})$ to the end of experiment $(32.76,31.6$ and $33.6 \mathrm{mg} / \mathrm{l})$, respectively (Fig. 2). In contrast, values in control was increased from $33.45 \mathrm{mg} / \mathrm{l}$ to $33.9 \mathrm{mg} / \mathrm{l}$. The $C d$ treatment had the best phosphorus removal $(4.4 \%)$ with average concentrations of $32.25 \mathrm{mg} / \mathrm{l}$ followed by $\mathrm{Lm}$ treatment $(1.9 \%)$ with average of $33.08 \mathrm{mg} / \mathrm{l}$, while $\mathrm{Lm}+\mathrm{Cd}$ treatment had no effect when compared to the control. As comparison, Muradov et al. (2014) found that at initial $\mathrm{TPO}_{4}$ of $24.7 \mathrm{mg} / \mathrm{l}$, a removal efficiency from wastewater by using $L$. minor (duckweed) and azolla plant was $11.3 \%$ and $4.9 \%$, respectively. Moreover, $\mathrm{Xu}$ and Shen (2011) found that at initial $\mathrm{TPO}_{4}$ concentration of $30.6 \mathrm{mg} / \mathrm{l}$, removal efficiency by duckweed from wastewater was $24 \%$. Also, Sudiarto et al., (2019) found that Limna sp had the highest phosphorus removal of 36.15\%. Alvarado et al. (2008) and Gao et al., (2009) reported that the plants removal capacity increased with the increment in nitrogen and phosphorus in water. Foroughi (2011) agreed with our findings and reported that $C$. demersum could absorb high amount of calcium, nitrogen, phosphorous، sodium and potassium efficiently from aquatic environments.

\section{Hematological analyses}

Hematological parameters are used as indicators of fish health status in many fish species by detecting physiological changes occurring after different stresses such as exposure to pollutants, diseases, minerals, and hypoxia (El-Sayed, 2015). Hematological indices are of different sensitivity to various environmental factors and chemicals. They are highly dependent on the change of water quality. All hematology analyses of the present work are summarized in Table (2).

White blood cell (WBC) count in all plant treatments was found to be significantly less than the control, reflecting less contamination due to these treatments. As contamination increases, the defensive mechanisms against the toxic effect of pollutants increases, and this may explain the increase in WBCs in the more contaminated control.

Table 2: Hematological variables of tilapia (Oreochromis niloticus) after culture with Lemna minor (Lm), Ceratophyllum demersum $(\mathrm{Cd})$ or mix of them $(\mathrm{Lm}+\mathrm{Cd})$.

\begin{tabular}{|c|c|c|c|c|}
\hline \multirow{2}{*}{ variables } & \multicolumn{4}{|c|}{ Treatments } \\
\hline & Control & $L m$ & $C d$ & $\mathrm{Lm}+\mathrm{Cd}$ \\
\hline RBC $\left(10^{6} / \mathrm{uL}\right)$ & $1.6 \pm 0.02$ & $2.0 \pm 0.06^{\mathrm{a}}$ & $2.2 \pm 0.02^{\mathrm{a}, \mathrm{b}}$ & $1.9 \pm 0.01^{\mathrm{a}}$ \\
\hline WBC $\left(10^{3} / \mathrm{uL}\right)$ & $56.3 \pm 0.06$ & $33.7 \pm 0.04^{\mathrm{a}, \mathrm{b}}$ & $33 \pm 0.04^{\mathrm{a}, \mathrm{b}}$ & $34.7 \pm 0.05^{\mathrm{a}, \mathrm{b}}$ \\
\hline $\mathrm{Hb}(\mathrm{g} / \mathrm{dL})$ & $5 \pm 0.09$ & $6.8 \pm 0.02^{\mathrm{a}, \mathrm{b}}$ & $7.2 \pm 0.05^{\mathrm{a}, \mathrm{b}}$ & $5.9 \pm 0.05^{\mathrm{a}, \mathrm{b}}$ \\
\hline Het $(\%)$ & $24.68 \pm 0.19$ & $30.68 \pm 0.21^{\mathrm{a}, \mathrm{b}}$ & $39.31 \pm 0.12^{\mathrm{a}, \mathrm{b}}$ & $27.94 \pm 0.08^{\mathrm{a}, \mathrm{b}}$ \\
\hline MCV (fl) & $139.9 \pm 0.29$ & $160.6 \pm 0.05^{\mathrm{a}, \mathrm{b}}$ & $181.7 \pm 0.17^{\mathrm{a}, \mathrm{b}}$ & $155.4 \pm 0.08^{\mathrm{a}, \mathrm{b}}$ \\
\hline МCH (pg) & $34.1 \pm 0.12$ & $33.3 \pm 0.12^{\mathrm{a}, \mathrm{b}}$ & $30.9 \pm 0.09^{\mathrm{a}, \mathrm{b}}$ & $31.4 \pm 0.05^{\mathrm{a}, \mathrm{b}}$ \\
\hline $\operatorname{MCHC}(\mathrm{g} / \mathrm{dL})$ & $24 \pm 0.58$ & $19 \pm 0.57^{\mathrm{a}}$ & $18 \pm 1.13^{\mathrm{a}, \mathrm{c}}$ & $20 \pm 1.16^{\mathrm{a}}$ \\
\hline
\end{tabular}

Parameters were measured after 4 weeks of experimentation. Data are presented as mean \pm SEM. Statistical analyses: ANOVA $\mathrm{p}<0.05$ for all parameters. Unpaired t-test: $\mathrm{a}=$ significantly different from the control value, $\mathrm{b}$ $=$ significantly different from values of other treatments, $\mathrm{c}=$ significantly different from the value of the mixed treatment only. 
As well, red blood cell count (RBCs), hemoglobin ( $\mathrm{Hb})$, hematocrit (Hct) and mean corpuscular volume (MCV) was significantly higher in plant treatments than that of the control (Table 2). RBCs, Hb, Hct, MCV, were enhanced and increased by ranges of (18.8-37.5\%) for RBCs, (18-44\%) for $\mathrm{Hb},(13.2-59.3 \%)$ for Hct, and (11$29.9 \%$ ) for $\mathrm{MCV}$. The maximum enhancement in hematological indices was recorded in fish collected from $C d$ treatment by an average of $20 \%$ followed by $\mathrm{Lm}$ treatment $(9.6 \%)$ and $C d$ treatment $(2.45 \%)$. These changes may also reflect less water pollution due to the phytoremediation.

Some researchers showed that the major outcome of nitrite poisoning is the oxidation of hemoglobin to methemoglobin in erythrocytes (González et al., 2000; Svobodova et al., 2005; Kroupovaa et al., 2008). Consequently blood oxygen transport is compromised, since methemoglobin does not bind oxygen. On the other hand, mean corpuscular hemoglobin $(\mathrm{MCH})$, and mean corpuscular hemoglobin concentration (MCHC) were significantly higher in the control fish than the other treatments. $\mathrm{MCH}$ and $\mathrm{MCHC}$ levels were reduced in fish collected from the plant treated groups by a range of (38.4-41.4\%), (2.34-9.4\%), and (16.7-25\%), respectively, than control. Such changes were highly related to pollutants increase, the reduction of dissolved oxygen in water during the experiment, and the defensive mechanisms against the toxic effect of pollutants which cause disturbances to the metabolic and hematopoietic activities in fish (Katalay\&Parlak, 2004; Javed and Usmani, 2013; Praveena et al., 2013). Nevertheless, many reports (Jee et al., 2004; Saravanan et al., 2011; Fazio et al., 2013) showed that MCHC and MCH values were decreased in respect to control group in fish exposed to different agents.

White blood cell (WBC) count in all plant treatments was found to be significantly less than the control, reflecting less contamination due to these treatments. As contamination increases, the defensive mechanisms against the toxic effect of pollutants increases, and this may explain the increase in WBCs in the more contaminated control.

As well, red blood cell count (RBCs), hemoglobin ( $\mathrm{Hb})$, hematocrit (Hct) and mean corpuscular volume (MCV) was significantly higher in plant treatments than that of the control (Table 2). RBCs, Hb, Hct, MCV, were enhanced and increased by ranges of (18.8-37.5\%) for RBCs, $(18-44 \%)$ for $\mathrm{Hb},(13.2-59.3 \%)$ for $\mathrm{Hct}$, and (11$29.9 \%$ ) for $\mathrm{MCV}$. The maximum enhancement in hematological indices was recorded in fish collected from $C d$ treatment by an average of $20 \%$ followed by $\mathrm{Lm}$ treatment $(9.6 \%)$ and $C d$ treatment $(2.45 \%)$. These changes may also reflect less water pollution due to the phytoremediation. Some researchers showed that the major outcome of nitrite poisoning is the oxidation of hemoglobin to methemoglobin in erythrocytes (González et al., 2000; Svobodova et al., 2005; Kroupovaa et al., 2008). Consequently blood oxygen transport is compromised, since methemoglobin does not bind oxygen. On the other hand, mean corpuscular hemoglobin $(\mathrm{MCH})$, and mean corpuscular hemoglobin concentration (MCHC) were significantly higher in the control fish than that in the other treatments. $\mathrm{MCH}$ and $\mathrm{MCHC}$ levels were reduced in fish collected from the plant treated groups by a range of (38.4-41.4\%), $(2.34-9.4 \%)$, and (16.7-25\%), respectively, than control. Such changes were highly related to pollutants increase, the reduction of dissolved oxygen in water during the experiment, and the defensive mechanisms against the toxic effect of pollutants which cause disturbances to the metabolic and hematopoietic activities in fish (Katalay\&Parlak, 2004; Javed and Usmani, 2013; Praveena et al., 2013). Nevertheless, many reports (Jee et al., 2004; Saravanan et al., 2011; Fazio et al., 
2013) showed that MCHC and $\mathrm{MCH}$ values were decreased in respect to control group in fish exposed to different agents.

\section{Liver function}

It is well-known that fish serum hepatic enzymes increase as water pollution increases (Matsue et al., 2004; Sbai and Rabeh, 2006; Hadi et al. 2009; Osman et al., 2018). It has also been reported that changes in serum hepatic enzyme activity directly point to major pathological changes or liver damage (Bhattacharya et al., 2008). Our results (Fig. 3) revealed a significant reduction in the concentrations of serum AST and ALT in fish of plant treated groups compared to the control group.

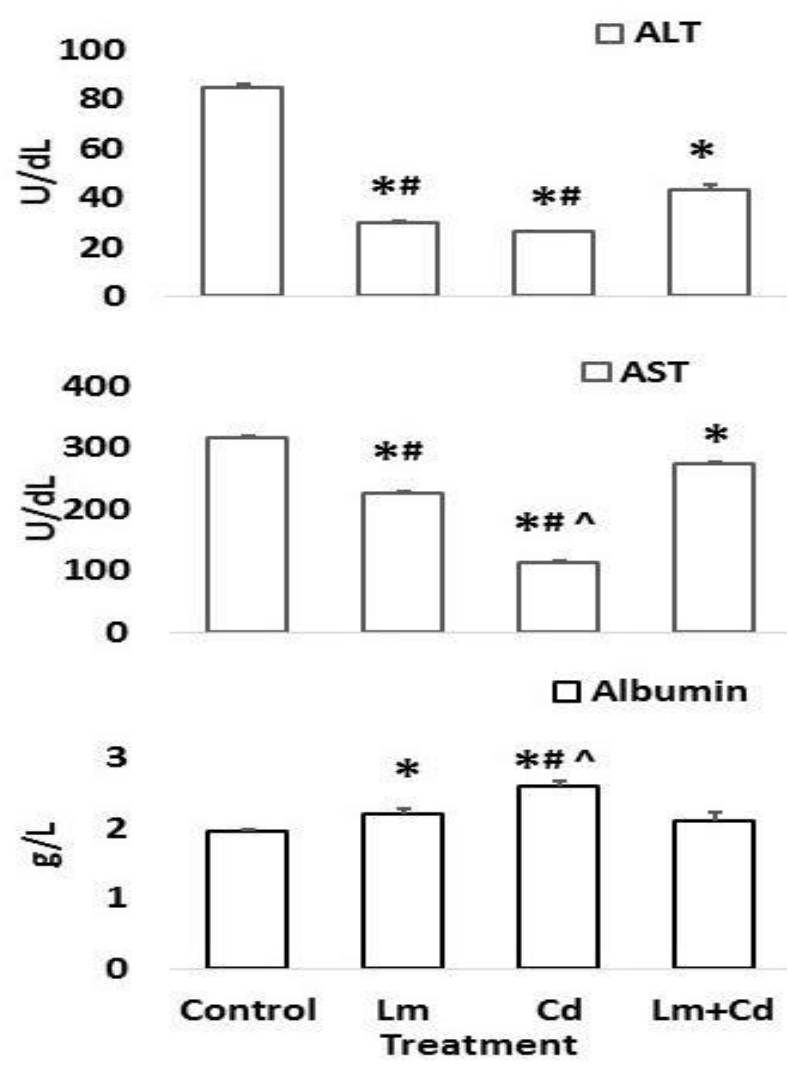

Fig. 3: Liver function tests in tilapia after 4-week-culture with Lemna minor (Lm), Ceratophyllum demersum $(C d)$ or mix of them $(L m+C d)$. Data are presented as mean \pm SEM. Statistical analysis: ANOVA $\mathrm{p}<0.05$ for all parameters. Unpaired t-test: $*=$ significantly different from the control value, \# = significantly different from values of the mixed treatment, $\wedge=$ significantly different from the value of the other single plant treatment.

Single plant treatment was also found to be superior to the mixed treatment, and $C d$ was superior to $L m$ treatment. In consistence with these results, albumin was found to be dropped in the control group, in comparison with the both single plant treated groups. Again, treatment with $C d$ was superior to other treatments. $C d$ treatment exerted a maximum reduction in hepatic enzymes: 64\% for AST and $69.3 \%$ for ALT, compared to the control. The decreases of hepatic enzymes and the increase in plasma albumin can be attributed to the clearance of pollutants and low levels of organic matter in water with these treatments. Several reports indicated that the high levels of serum AST and ALT in O. niloticus are due to high ammonia levels in water and they play an important role in detoxification of ammonia in fish (Min and Kang, 2008). These reports are in agreement with the results of the present work. Change in the blood cholesterol and triglyceride concentration (Fig. 5) is a 
sensitive indicator of liver dysfunction too, because homeostasis of lipids is one of the principle liver functions (Sayed et al., 2011). It has been reported that exposure of fish to pollutants increased cholesterol and triglyceride concentrations in the blood. In the present work, blood cholesterol and triglyceride levels were significantly $(\mathrm{p}<0.05)$ higher in control fish compared to all other treatments. Such increases could be explained as a result of liver damage, leading to inhibition of enzymes that converts cholesterol into bile acid (Osman 2012).

\section{Kidney function}

The results (Fig. 4) exhibited higher levels of serum creatinine, urea, and uric acid in the control fish blood compared to plant treatments. This increase can be attributed to the increased concentrations of pollutants in water (Hadi et al., 2009). The increased levels of serum creatinine, urea, and uric acid are significant indicators of kidney malfunction and increased muscular tissue catabolism (Pandey et al., 2003). Creatinine rise might be induced by glomerular insufficiency, increased muscle tissue catabolism or the impairment of carbohydrate metabolism (Sevgiler et al., 2004; Abu et al., 2009; Zaki et al., 2010; Kamal and Omar, 2011). Similar findings were reported by Zaki et al. (2010) who recorded a significant increase in these parameters in Nile tilapia due to cadmium exposure. Treatment with $C d$ exerted the maximum reduction: for uric acid (53\%), urea (29.62\%), and creatinine (24\%), compared to the other treatments and control.

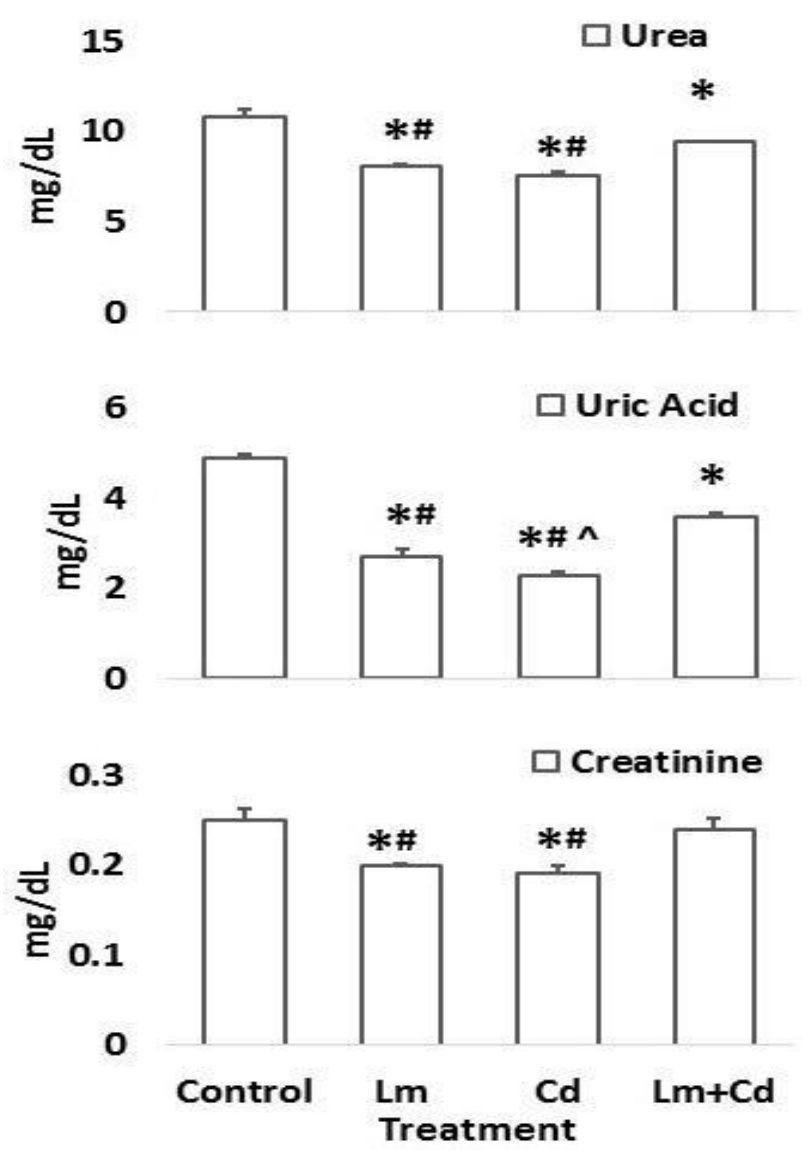

Fig. 4: Kidney function tests in tilapia after 4 week culture with Lemna minor (Lm), Ceratophyllum demersum $(C d)$ or mix of them $(L m+C d)$. Data are presented as mean \pm SEM. Statistical analysis: ANOVA $\mathrm{p}<0.05$ for all parameters. Unpaired t-test: $*=$ significantly different from the control value, \# = significantly different from values of the mixed treatment, $\wedge=$ significantly different from the value of the other single plant treatment. 


\section{Nutritional aspects}

Biochemical blood indices were measured for fish in all treatments (Fig. 5). Protein and albumin levels were increased in the three treatments by range of (6.7$53.3 \%)$ and (7.7-33.3\%), respectively, compared with the control. $C d$ treatment exerted a maximum reduction: for cholesterol (28.9\%), triglyceride $(63.24 \%)$, and glucose $(88.5 \%)$, compared to the other treatments and control.
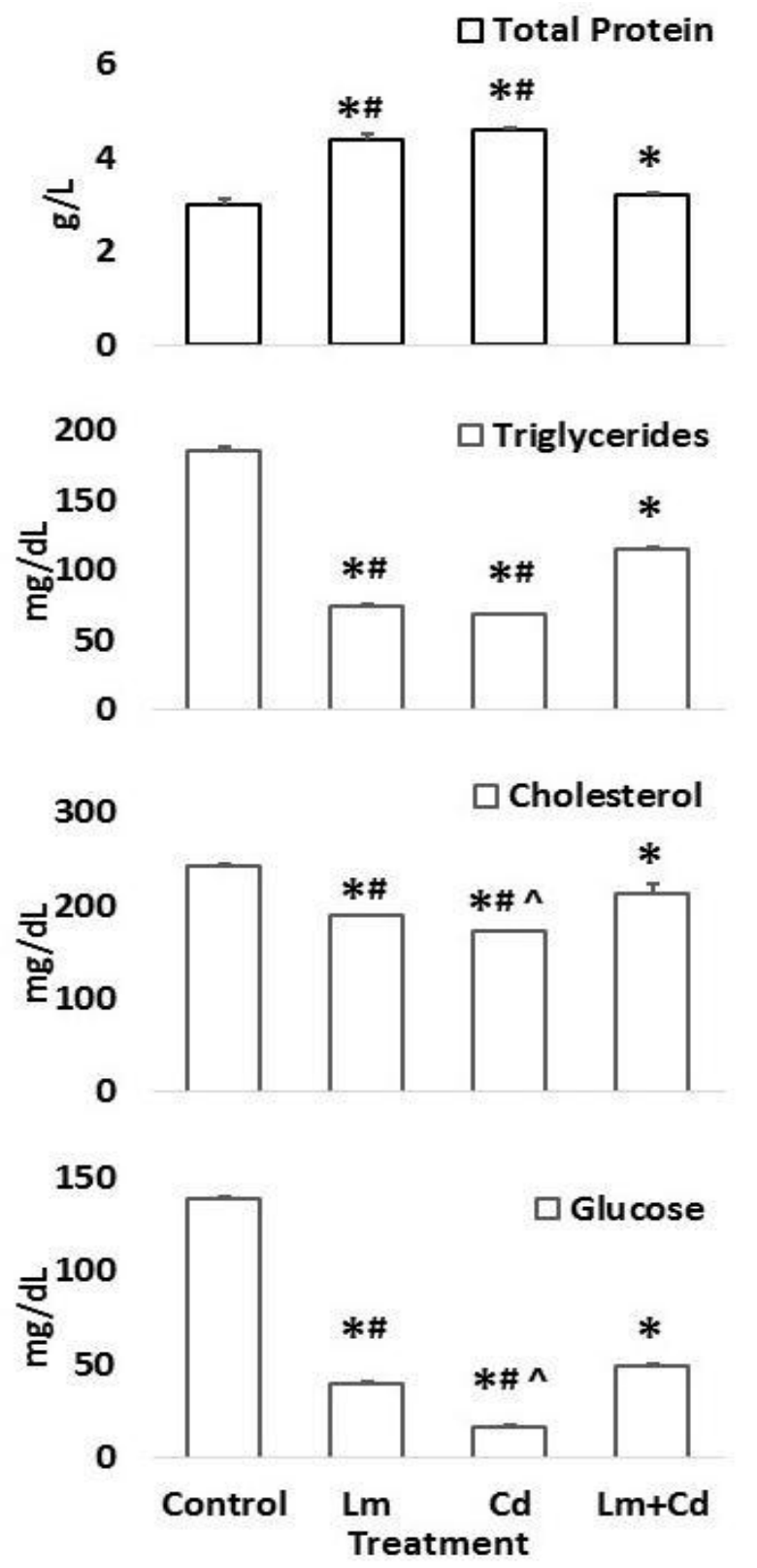

Fig. 5: Plasma nutritional profile (total protein, lipids, cholesterol and glucose) in tilapia after 4 week culture with Lemna minor $(\mathrm{Lm})$, Ceratophyllum demersum $(\mathrm{Cd})$ or mix of them $(\mathrm{Lm}+\mathrm{Cd})$. Data are presented as mean \pm SEM. Statistical analyses: ANOVA $p<0.05$ for all parameters. Unpaired t-test: $*=$ significantly different from the control value, \# = significantly different from values of the mixed treatment, ${ }^{\wedge}=$ significantly different from the value of the other single plant treatment.

The protein synthesis of an organism is an important issue because of its involvement in enzymes, hormones, and antibodies. Thus, the influence of toxicants on total protein concentration of fish has been taken into consideration to evaluate 
the response to stressors and consequently the increasing demand for energy (Hadi et al., 2009). In the present study, the total plasma protein concentration of tilapia was significantly increased in plant-treated groups when compared to the control groups (Fig. 5). Several reports indicated a decline of total protein and albumin in blood serum as a result of exposure to toxins (Mutlu et al., 2015; and Li et al., 2018). Other reports indicated that total protein increases increase liver dysfunction due to higher heavy metal concentrations (Zaki et al., 2010).

A decrease in plasma total lipids and cholesterol in plant treated groups as compared with the control (Fig. 5) is a good indicator of liver function, as mentioned above. In this context, single plant treatment was superior to the mixed treatment, and $C d$ was superior to $L m$ treatment.

Levels of blood glucose were used as an indicator of environmental stress to reflect changes in carbohydrate metabolism in stress conditions (Kamal and Omar, 2011). Glucose levels were significantly higher in the control fish blood than in the other treatment. This increase can be due to changes in the chemical parameters of water. Chemical pollutants modulate the metabolism of carbohydrates, causing high blood sugar by stimulating glycolysis in fish (Levesque et al., 2002), and is probably linked to trying to mobilize energy resources to deal with tension and maintain balance (Ackerman et al., 2006). Increased levels of glucose were previously recorded in blood of fishes exposed to ultraviolet radiation (Sayed et al., 2007), heavy metals (Mekkawy et al., 2010), and other pollutants (Adedeji et al., 2009; Osman et al., 2010).

\section{CONCLUSION}

This study was conducted to evaluate the suitability and efficacy of using either Ceratophyllum demersum, Lemna minor or a mixture of both plants in treating tilapia aquaculture wastewaters. A reasonable reduction in concentrations of turbidity, conductivity, TDS, COD, BOD, and nutrients was observed after treatment with either $C$. demersum or L. minor. Results of water quality and fish physiology revealed that $C$. demersum was quite effective in treating the aquaculture wastewaters compared to the other treatments .Therefore, it is advisable to use $C$. demersum in treating aquaculture wastewater or inclusion in tilapia cultures.

\section{ACKNOWLEDGEMENT}

Supported by the grant from the Academy of Scientific Research and Technology (ASRT), Egypt.

\section{REFERENCES}

Abu, O.M.G.; Gabriel, U.U.; Sanni, L.O. and Akinrotimi, O.A. (2009). Evaluatoin of Biochemical Changes Associated with Replacement of Maize with Whole Cassava Root Meal in the Diet of Hybrid Catfish. J Aquacult Feed Sci and Nutr, 1: 68-72.

Ackerman, P. A.; Wicks, B. J.; Iwama, G. K. and Randall, D. J. (2006). Low level of environmental ammonia increase susceptibility to disease in Chinook Salmon Smolts. Physiol. Biochem. Zool., 79 (4): 695-707 
Adedeji, O.B.; Adeyemo, O.K. and Agbede, S. A. (2009). Effects of diazinon on blood parameters in the African catfish (Clarias gariepinus). African J Biotechnol, 8: 3940-3946.

Ahmed, M. A.; Aly, A. I. M. and Hussien, R. A. (2013). Human-induced and eutrophication impacts on physiochemical and isotopic water characteristics of a northeastern Nile Delta Lake, Egypt. Arab J. Nuclear Sci. Applicat., 46(1): 117.

Alvarado, S.; Guédez, M. and Lué-Merú, M.P. (2008). Arsenic removal from waters by bioremediation with the aquatic plants Water Hyacinth (Eichhornia crassipes) and Lesser Duckweed (Lemna minor). Bioresour. Technol. 99: 8436-8440.

Amare E.; Kebede F. and Mulat W. (2018).Wastewater treatment by Lemna minor and Azolla filiculoides in tropical semiarid regions of Ethiopia. Ecol. Eng., 120: 464-473.

APHA .(2005). Standard methods for the examination of waterand wastewater. (Amer Public Health Assn).

Aravind, P. and Prasad, M.N.V. (2005). Modulation of cadmium induced oxidative stress in Ceratophyllum demersum by zinc involves ascorbate-glutathione cycle and glutathione metabolism. Plant Physiol. Biochem., 43: 107-116.

Ayoola, S.O.; Adejumobi, K.O. and Adamson, O.H. (2014). Haematological Indices and Enzymatic Biomaker of black jaw tilapia (Sarotherodon melanotheron) from Lagos Lagoon. Agrosearch, 14(1): 62-75.

Beheary, S.M.; Abu-Almaaty, A.H. and El-matary, F. (2015). Genetic Polymorphism and changes in the concentration of heavy metals in catfish "Clarias gariepinus" from different sites as a result of environmental contamination. Adv. Environ. Boil., 9: 20-32.

Beheary, S.M. and El-matary, A. F. (2018a). Bioaccumulation of Heavy Metals and Implications Associated with Consumption of the Thinlip Mullet (Liza ramada) Collected from Sites of Varying Salinity, Asian J. Fish. Aq. Res., 2(2): 1-15.

Beheary, S.M.; El-matary, A.F.; Abd El Hamid, T.H. and Al Tawaha, A.R.M. (2018b). Environmental risk assessment of heavy metals contamination in industrial drain connected to Mediterranean Sea, Adv. Environ. Biol., 12(11): $1-13$.

Bhattacharya, H.; Xiao, Q. and Lun, L. (2008). Toxicity studies of nonylphenol on rosy barb (Puntius conchonious): A biochemical and histopathological evaluation. Tissue Cell, 40: 243-249.

Brain, R.A. and Solomon, K.R., (2007). A protocol for conducting 7-day daily renewal tests with Lemna gibba. Nature Protocols, 2(4): 979.

Britto, D.T., and Kronzucker, H.J. (2002). NH4CToxicity in Higher Plants: A Critical Review. J. Plant Physiol., 159: 567-584.

El-Kheir, W.A.; Ismail, G. and El-Nour, F. A. (2007). Assessment of the efficiency of duckweed (Lemna gibba) in wastewater treatment. Int. J. Agric. Biol., 9 (5): 681-687.

El-Sayed, E.S.E.B. (2015). Accumulation of some heavy metals and its effect on hematological indices of fresh water fish, Oreochromis niloticus. Egypt. J. of Aquatic Biol. Fish., 287, 1-13.

Fang, Y.Y.; Babourina, O.; Rengel, Z.; Yang, X.E. and Pu, P.M. (2007). "Ammonium and Nitrate Uptake by the Floating Plant Landoltia punctate. Annals Botany, 99: 365370. 
Fazio, F.; Faggio, C.; Marafioti, S.; Torre, A.; Sanfilippo, M. and Piccione, G. (2013). Effect of water quality on hematological and biochemical parameters of Gobius niger caught in Faro lake (Sicily). Iran. J. Fish. Sci., 12(1): 219-231.

Foroughi, M. (2011). Role of Ceratophyllum demersum in recycling macro elements from wastewater. J.Appl. Sci. Environ. Manag., 15: 2.

Foroughi, M.; Najafi, P.; Toghiani, A. and Honarjoo, N. (2010). Analysis of pollution removal from wastewater by Ceratophyllum demersum. African J. Biotechnol., 9(14): 2125-2128.

Foroughi, M.; Najafi, P.; Toghiani, S. and Honarjoo, N. (2014). Using Ceratophyllum demersum for Treatment of Saline Municipal Wastewater. J. Residuals Sci. Technol., 11(2): 45-48.

Gao J.; Xiong ZH.; Zhang J.; Zhang W. and Obono M. (2009). Phosphorous removal from water of eutrophic Lake Donghu by five submerged macrophytes, Desalination, 242: 193-204.

González, J. F., Del Valle, P. L., Thohan, S. and Kane, A. S., (2000). Effects of waterborne nitrite on phase I-II biotransformation in channel catfish (Ictalurus punctatus), Marine Environ. Res., 50: 29-32.

Gopal, B., and Ghosh, D., (2008). Natural wetlands. In: Jørgensen, S.E. (Ed.), Applications in Ecological Engineering, first ed. Elsevier B.V., Amsterdam, The Netherlands.

Gupta, C. and Prakash, D. (2014). Duckweed: an effective tool for phytoremediation. Toxicol. Environ. Chem., 95(8): 1256-1266.

Hadi, A. A.; Shokr, A. E. and Alwan, S. F. (2009). Effects of aluminum on the biochemical parameters of fresh water fish, Tilapia zillii. J. Sci. Appl., 3(1): 33-41.

Hasan, M.R. and Chakrabarti, R.. (2009). Use of algae and aquatic macrophytes as feed in small-scale aquaculture: FAO Fisheries and Aquaculture Technical Paper., 531

Huang, L., Y. Lu, X. Gao, G. Du, X. Ma, M. Liu, J. Cuo, and J. Chen. (2013). Ammonium-Induced Oxidative Stress on Plant Growth and Antioxidative Response of Duckweed (Lemna minor L.). Ecol. Eng., 58: 355-362.

Iamchaturapatr, J., Yi, S.W. and Rhee, J.S. (2007). Nutrient removals by 21 aquatic plants for vertical free surface-flow (VFS) constructed wetland. Ecol. Eng., 29: 287-293.

Islam M., and Tanaka M (2004). Impacts of pollution on coastal and marine ecosystems including coastal and marine fisheries and approach for management: a review and synthesis, Mar. Pollut. Bull., 48: 624-649.

Javed, M. and Usmani, N. (2013). Haematological indices of Channa punctatus as an indicator of heavy metal pollution in waste water aquaculture pond, Panethi, India. Afri. J. of Biotech., 12(5): 520-525.

Jee, J. H., Kim, S. G. and Kang, J. C. (2004). Effects of phenanthrene on growth and basic physiological functions of the olive flounder, Paralichtys olivaceus. Journal of Experimental Marine Biol. Ecol., 304: 123-136.

Kamal, S.M. and Omar, W.A. (2011). Effect of Different Stocking Densities on Hematological and Biochemical Parameters of Silver Carp, Hypophthalmichthys molitrix Fingerlings. Life Sci. J., 8: 580-586.

Kashim, M.A. and Singh, B.R. (2002). The effect of fertilizer additions on the Solubility and plant-availability of $\mathrm{Cd}, \mathrm{Ni}$ and $\mathrm{Zn}$ in soil. Nutrient Cycling Agro Ecosyst, 62(3): 287-296. 
Katalay, S. and Parlak, H. (2004). The effects of pollution on haematological parameters of black goby (Gobius niger L., 1758) in Foça and Aliağa Bays. J. Fish. Aq. Sci., 21: 113-117.

Koèrner, S. and Vermaat, J.E. (1998). The relative importance of Lemna Gibba L., bacteria and algae for the nitrogen and phosphorus removal in duckweedcovered domestic wastewater. Water Res., 32: 3651-3661.

Korner, S.; Vermaat, J.E. and Veenstra, S. (2003). The capacity of duckweed to treat wastewater: ecological considerations for a sound design. J. Environ. Q., 32: $1583-1590$.

Kroupovaa, H.; Machovaa, J.; Piackovaa, V.; Blahovab, J.; Dobsikovab, R.; Novotnyb, L. and Svobodova, Z. (2008). Effects of subchronic nitrite exposure on rainbow trout (Oncorhynchus mykiss). Ecotoxicol. Environ. Safety, 71: 813- 820 .

Levesque, H.M.; Moon, T.W.; Campbell, P.G.C. and Hontela, A. (2002). Seasonal variation in carbohydrate and lipid metabolism of yellow perch (Perca flavescens) chronically exposed to metals in the field. Aquatic Toxicol, 60, 257-267.

Li, C.; Zhang, M.; Li, M.; Zhang, Q.; Qian, Y. and Wang, R. (2018). Effect of dietary alanyl-glutamine dipeptide against chronic ammonia stress induced hyperammonemia in the juvenile yellow catfish (Pelteobagrus fulvidraco). Comp. Bioch. Physiol., 213: 55-61.

Louis, L.; Nick, C.P. and Clifford, B.F. (2005). Modeling duckweed growth in wastewater treatment systems. Livestock Res. Rural Dev., 17: 6.

Matsuo, A.Y.; Playle, R.C.; Val, A.L. and Wood, C.M. (2004). Physiological action of dissolved organic matter in rainbow trout in the presence and absence of copper: sodium uptake kinetics and unidirectional flux rates in hard and soft water. Aquat. Toxicol., 18: 70(1): 63-81.

Mekkawy, I.A.A.; Mahmoud, U.M.; Wassif, E.T. and Naguib, M. (2010). Effects of cadmium on some haematological and biochemical characteristics of Oreochromis niloticus (Linnaeus, 1758) dietary supplemented with tomato paste and vitamin E. Fish physiol Biochem, 37: 71-84.

Metcalf and Eddy. Inc. (2003). Wastewater Engineering: Treatment and Reuse. 4th Edition, McGraw-Hill, New York.

Min, E. Y. and Kang, J. (2008). Effect of water borne benomyl on the hematological parameters of the Nile tilapia, Oreochromis niloticus. Pest. Biochem. and Physiol., 92(3): 138-143.

Mohedano, R.A.; Costa, R.H.; Tavares, F.A. and Belli Filho, P. (2012). High nutrient removal rate from swine wastes and protein biomass production by full-scale duckweed ponds. Bioresour. Technol., 112: 98-104.

Muradov, N.; Taha, M.; Miranda, A.F.; Kadali, K.; Gujar, A.; Rochfort, S.; Stevenson, T.; Ball, A.S. and Mouradov, A. (2014). Dual application of duckweed and azolla plants for wastewater treatment and renewable fuels and petrochemicals production. Biotechnol. Biofuels, 7: 30 .

Mutlu, E.; Aydin, S. and Kutlu B. (2015). Alterations of Growth Performance and Blood Chemistry in Nile Tilapia (Oreochromis Nuoticus) Affected by Copper Sulfate in Long-Term Exposure. Turkish J. Fish. Aq. Sci., 15: 487- 493.

Osman, A.G.; Koutb, M. and Sayed, A.H. (2010). Use of hematological parameters to assess the efficiency of quince (Cydonia oblonga Miller) leaf extract in alleviation of the effect of ultraviolet--A radiation on African catfish Clarias gariepinus (Burchell, 1822). J photochem photobiol B-biol., 99: 1-8. 
Osman, A.G. (2012). Biomarkers in Nile tilapia Oreochromis niloticus niloticus (Linnaeus, 1758) to assess the impacts of river Nile pollution: bioaccumulation, biochemical and tissues biomarkers. J Environ. Protect., 3: 966-977.

Osman, A.G.; AbouelFadl, K.Y.; Abd El Baset, M.; Mahmoud, U.M.; Kloas, W. and Moustafa, M.A. (2018). Blood Biomarkers in Nile tilapia Oreochromis niloticus niloticus and African Catfish Clarias gariepinus to Evaluate Water Quality of the River Nile. J. Fish. Sci., 12(1): 1-15.

Pandey, S.; Parvez, S.; Sayeed, I.; Haque, R.; Bin- Hafeez, B. and Raisuddin, S. (2003). Biomarkers of oxidative stress: a comparative study of river Yamuna fish. Wallago attu. Sci. Total Environ., 309: 105-15.

Pilon-Smits, E. (2005). Phytoremediation. Annu. Rev. Plant Biol., 56: 15-39.

Praveena, M.; Sandeep, V.; Kavitha, N. and Jayantha Rao K. (2013). Impact of Tannery Effluent, Chromium on Hematological Parameters in a Fresh Water Fish, Labeo Rohita (Hamilton). Res. J. Animal, Vet. Fish. Sci., 1(6): 1-5

Sabae, S. Z. and Rabeh, S. A. (2006). Evaluation of the microbial quality of the River Nile waters at Dameitta branch. Egypt., Egypt. J. Zool., 31: 312 - 319.

Saha,P.; Banerjee A.; and Sarkar S. (2015). Phytoremediation Potential of Duckweed (Lemnaminor L.) On Steel Wastewater, Int. J. Phytoremediation, 17: 589-596.

Saravanan, M.; Prabhu, K. and Ramesh, M. (2011). Haematological and biochemical responses of freshwater teleost fish Cyprinus carpio (Actinopterygii: Cypriniformes) during acute and chronic sublethal exposure to lindane. Pest. Biochem. Physiol., 100: 206-211.

Sayed, A.H.; Ibrahim, A.T.; Mekkawy, I.A.A. and Mahmoud, U.M. (2007). Acute effects of Ultraviolet-A radiation on African Catfish Clarias gariepinus (Burchell, 1822). J Photochem Photobiol B-Biol, 89: 170-174.

Sayed, A.H.; Mekkawy, I.A. and Mahmoud, U.M. (2011). Effects of 4-nonylphenol on metabolic enzymes, some ions and biochemical blood parameters of the African catfish Clarias gariepinus (Burchell, 1822). African J Biochem Res., 5: 287-297.

Seo, B.S.; Park, C.M.; Song, U. and Park, W.J. (2010). Nitrate and phosphate removal potentials of three willow species and a bald cypress from eutrophic aquatic environment. Landsc. Ecol. Eng., 6: 211-217.

Sevgiler, Y.; Oruc, E. O. and Uner, N. (2004). Evaluation of etoxazole toxicity in the liver of Oreochromis niloticus Pest. Biochem. Physiol., 78(1): 28-38.

Sooknah, R.D. and Wilkie, A.C. (2004). Nutrient removal by floating aquatic macrophytes cultured in anaerobically digested flushed dairy manure wastewater. Ecol. Eng.، 22: 27-42.

Sudiarto, S.I.A.; Renggaman, A. and Choi, H.L. (2019). Floating aquatic plants for total nitrogen and phosphorus removal from treated swine wastewater and their biomass characteristics. J. Environ. Manag., 231: 763-769.

Svobodova, Z.; Machova, J.; Drastichova, J.; Groch, L.; Luskova, V.; Poleszczuk, G.; Velisek, J. and Kroupova, H. (2005). Haematological and biochemical profile of carp blood following nitrite exposure at different concentration of chloride. Aquaculture Res., 36: 1177-1184.

Tanner, C.C. and Headley, T.R. (2011). Components of floating emergent macrophyte treatment wetlands influencing removal of stormwater pollutants. Ecol. Eng., 37: 474-486.

Tel-Or, E. and Forni, C. (2011). Phytoremediation of hazardous toxic metals and organics by photosynthetic aquatic systems. Plant Biosyst., 145: 224-235. 
Wang, W.; Yang, C.; Tang, X.; Gu, X.; Zhu, Q.; Pan, K.; Hu, Q. and Ma, D. (2014). Effects of High Ammonium Levels on Biomass Accumulation of Common Duckweed Lemna minor L. Environmental Science and Pollution Research, 21: 14202-14210.

White, S.A. and Cousins, M.M. (2013). Floating treatment wetland aided remediation of nitrogen and phosphorus from simulated stormwater runoff. Ecol. Eng., 61: 207-215.

Wuang, S.C.; Khin, M.C.; Chua, P.Q.D. and Luo, Y.D. (2016). Use of Spirulina biomass produced from treatment of aquaculture wastewater as agricultural fertilizers. Algal research, 15: 59-64.

Xu, J.L. and Shen, G.X. (2011). Growing duckweed in swine wastewater for nutrient recovery and biomass production. Bioresource Technol., 102: 848-853.

Zaki, M.S.; Moustafa, S.; Fawzi, O.M.; El Bellbasi, H. and Syame, S. (2010). Assessment of the hazardous effect of lead Pollution on tilipia zilli , including hematological, Biochemical and immunological parameters. Report Opinion, 2: 82-89.

Zhang, K.; Chen, Y. P.; Zhang, T. T.; Zhao, Y.; Shen, Y.; Huang, L.; Gao, X. and Guo, J. S. (2014). The Logistic Growth of Duckweed (Lemna minor) and Kinetics of Ammonium Uptake. Environ. Technol., 35: 562-567.

Ziegler, P.; Sree, K. S. and Appenroth, K. J. (2016). Duckweeds for water remediation and toxicity testing. Toxicol. Environ. Chem., 98: 1127-1154.

\section{ARABIC SUMMARY}

\section{المعالجة البيئية لمياه صرف مزارع البلطي باستخدام نباتى عدس الماء Lemna minor ونخشوش الحوت Ceratophyllum demersum}

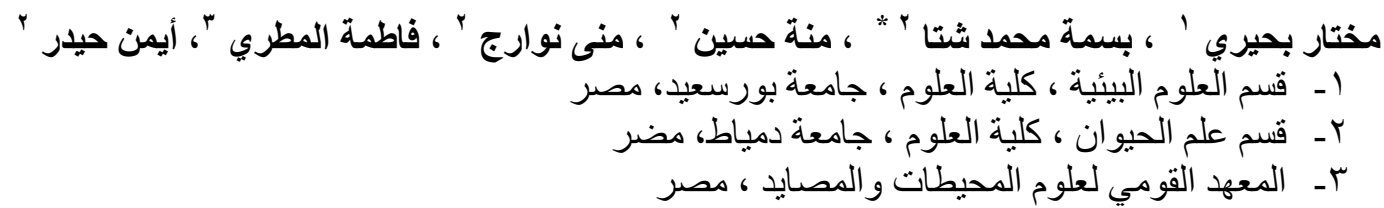

تم استخدام اثثين من النباتات الكبيرة المائية ، نخشوش الحوت Ceratophyllum demersum و عدس الماء Oreochromis ( Lemna minor

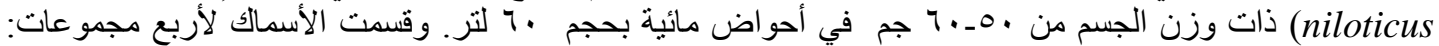

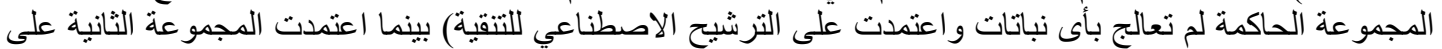

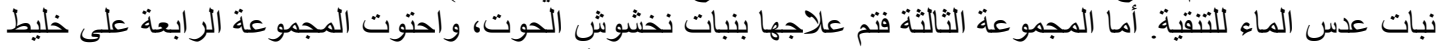

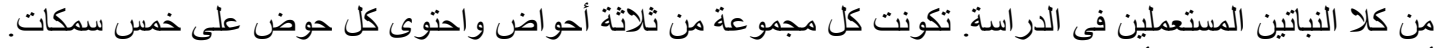

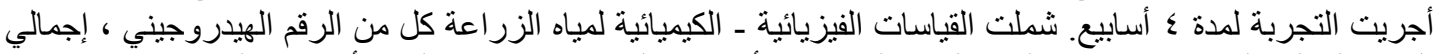

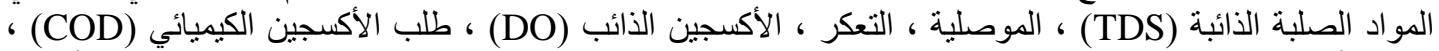

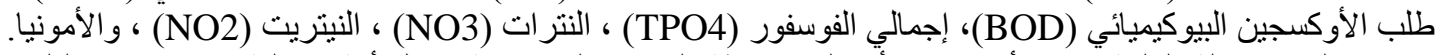

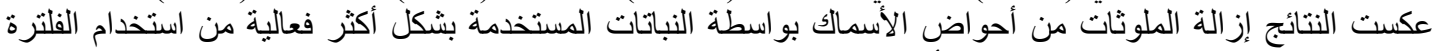

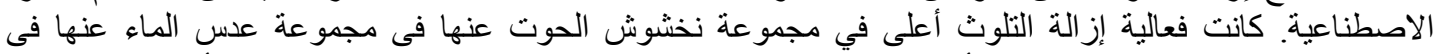

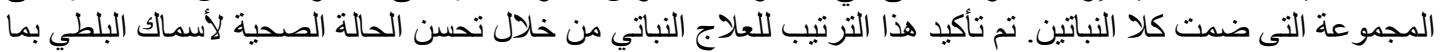

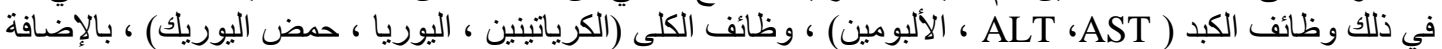

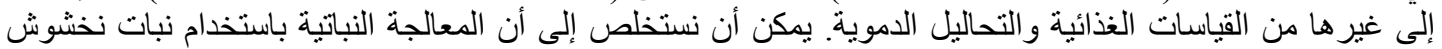

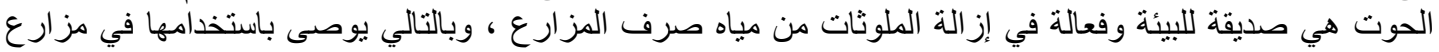

